\title{
Extreme Makeover CSI Edition: Tracing the Forensic Crime Drama's Engagement with Identity Crimes, Plastic Bodies and Self-Transformation Narratives
}

\section{SOFIA BULL}

\begin{abstract}
This article examines discourses on identity and bodily plasticity in the forensic crime drama CSI: Crime Scene Investigation (2000-). It argues that CSI engages with the same cultural debates as makeover reality $\mathrm{TV}$, but in ways that articulate a number of oppositional perspectives on self-transformation practices governed by the programme's investment in an essentialist and determinist understanding of genetics. The article traces CSI's reconfiguration of the motif of disguise and inverted use of generic tropes from makeover reality TV, as well as its tendency to worry about the increased possibilities for biomedical alterations of our bodies and genres, and concludes that the programme problematises self-transformation practices as a new type of 'identity crime'.
\end{abstract}

Key words: CSI: Crime Scene Investigation, makeover, identity, forensic science, genre

CSI: Crime Scene Investigation (2000-) has aired on television screens across the world with multiple re-runs for the last 14 years. It has turned a fictional team of Las Vegas criminalists into household names and played a crucial role in the wider construction of the forensic scientist as a popular icon of the early 2000s. As a result, the series' title sequence is instantly recognisable to many viewers. The flashing imagery of criminalists, forensic technologies and physical evidence is, fairly obviously, representative of the programme's evident thematic focus on scientific knowledge and practice. However, the music accompanying the familiar footage - the repetitive chorus from the song 'Who Are You?' by The Who-also calls forth another theme which goes to the heart of the programme: namely, identity and identifiability. Of course, the very act of identifying an unknown individual is a long-running generic trope that can be traced back through the history of the crime narrative. The question 'Who are you?' is implicitly posed each time a new dead body is located and it is the pivotal force behind every investigator's hunt for a missing perpetrator.

As I will outline, CSI belongs to a much longer history of crime narratives that promote forensic science as a particularly reliable toolkit for the identification of both victims and perpetrators. Classic crime generic tropes such as the figure of the disguised criminal and the notion of 'identity crimes' have been used to dramatise the reliability of forensic identification technologies for well over a century. However, cultural anxieties tied to the problem of hidden or mistaken identities have changed significantly over time. In this article I will examine CSI's historically specific discourse on bodily identity and identifiability by adopting an extended genre perspective that considers both long-running generic linkages and recent reconfigurations. I will examine how CSI's discourse on identity differs from some of its predecessors and propose that the programme engages with the same cultural debates as makeover reality TV: a genre that grew in popularity in parallel with the forensic crime drama in the early 2000 s and has bodily identity as a central theme.

My analysis of shared elements contributes to a wider study of television as a cultural forum (Newcomb and Hirsch 1983), by illustrating the advantage of examining that landscape more broadly across different genres. Tracing a particular cultural debate over texts rarely compared or even considered together provides new insights into the complex workings of the television medium and its genres. CSI's engagement with tropes more readily associated with makeover reality TV is a telling example of the dynamic engagement and 
crossbreeding performed by television, a medium that simultaneously renews and recycles itself in a continuous quest to appear both current and familiar. This analysis also aims to produce a more nuanced understanding of CSI's articulation of ideas about bodily identity. It is easy to assume that CSI's depiction of forensic identification practices simply produces a straightforward and powerful assertion of the identifiability of all bodies. However, I propose that $C S I$ conversely combines its investment in essentialist and neoliberal understandings of identity as static and unique with an active participation in contemporary cultural debates about the increased malleability of both our bodies and genes.

\section{Identity Crime and the Motif of Disguise in Early Crime Fiction}

Different forms of disguises are frequently used in CSI to illustrate the need for scientific methods of identification. The disguised criminal has long been a staple figure of the crime genre, commonly used to show the investigators' ability to unmask, and thus neutralise, perpetrators. On a general level, this motif plays with the basic idea that masks enable the wearer to pass as someone else, which by extension introduces the concept of disguise as an inherent threat to the act of identification. However, the associations tied to this trope have also changed over time; the disguised body has evoked different cultural anxieties at specific historical moments.

The motif of disguise has a long-running history in Western society. It was, for example, a central trope in Greek mythology (Murnaghan 1987). However, a number of cultural historians (Friedman 1991; Thomas 1999; Brooks 2007) have convincingly discussed the nineteenth century as a time in which the notion of masquerading became increasingly prominent, understood as a problematic element of modernity. At this point in time, the concept of 'identity crimes' emerged in both North America and Europe; acts such as impersonation, swindling and bigamy were increasingly discussed as antisocial behaviour and labelled as criminal acts. The popular media of the era played an important role in the construction of this new cultural anxiety, with the swindler (or the American 'confidence man') becoming a familiar figure in news media and popular fiction, particularly in crime narratives (Lindberg 1981). Lawrence M. Friedman $(1991,638)$ has argued that crimes of identity should actually be labelled as 'crimes of mobility', to stress the inherent link between social change destabilising old fixities of place and station in life and the increasing cultural worries about identity at this particular historical moment. This argument has been further articulated by Peter Brooks $(2007,152,157-8)$, who discusses urban growth and the social dislocation experienced during the nineteenth century as contributing factors to the inauguration of a new 'identity paradigm' in Western culture. At this point in time, a number of social and cultural institutions became newly concerned with establishing ways of defining, testing and knowing identity. In short, the perceived need to police and classify the population increased with the social and geographical mobility of modernity.

Furthermore, this social shift also helped stimulate the invention of many forensic technologies for identification (Friedman 1991, 638; Thomas 1999, 3-4; Brooks $2007,149,152)$. In his examination of forensic science in early detective fiction, Ronald R. Thomas $(1999,24)$ shows that the motif of disguise was quickly employed to dramatise scientific crime solving technologies (such as fingerprinting, mug shots and the lie detector) as useful tools for deciphering physical marks of identity and thus neutralise the perceived threat of crimes of mobility. Hence, Thomas' study suggests that early examples of crime fiction had already established the motif of disguise as a generic trope used to demonstrate the scientifically inclined investigator's ability to identify the criminal through particular bodily markers. CSI's use of the motif of disguise clearly follows in the footsteps of this generic tradition. It repeatedly depicts perpetrators disguising themselves with spectacular masks and 
costumes in order to dramatise the ability of the criminalists to access corporeal markers of identity and reveal their 'true' one. An illustrative example of this is the episode 'Living Legend' (7: 9), in which the investigation centres on a series of murders committed by Mickey Dunn (played by the lead singer of The Who, Roger Daltrey). Dunn is portrayed as a legendary gangster and 'master of disguise' who uses 'state of the art prosthetics' to pose as a Mexican fisherman, an overweight karaoke singer, an elderly Afro-American woman, and an old gangster friend. It is only when the criminalists compare the bone structure of the suspects' faces (as appearing on CCTV footage) that the singular bodily identity hiding behind the fake exteriors is revealed.

However, in spite of such apparent generic linkages to earlier crime narratives, a closer consideration of CSI's overall use of the motif of disguise points to a significant change in the cultural anxieties associated with identity crimes. One of Thomas' main points is that detective fiction from the nineteenth century tended to conflate personal with national identity. In other words, identity crimes were mainly posed as a problem of identifying the Other at a point in time when traditional boundaries surrounding both nation-states and classes were under threat from geographical and social mobility (Thomas 1999, 10, Friedman 1991, 650-4). Identity was understood as the equivalent of belonging to a social group or character type, as, for example, proposed by the nineteenth-century pseudo-sciences of phrenology and physiognomy. As a result, early examples of detective fiction used the motif of disguise to express the fear of certain groups able to hide their perceived Otherness, which according to the cultural ideals of the period should be clearly visible through corporeal signs. At this time, forensic science was thus specifically called on to sort out 'the familiar from the foreign' (Friedman 1991, 11).

Ellen Burton Harrington (2007, 370-2, 377-9) has already pointed out that CSI diverges from this older discourse when she examined the programme's depiction of forensic science to that in Arthur Conan Doyle's Sherlock Holmes narratives. Harrington rightly argues that CSI's overall discourse on identity is characterised by a more contemporary concern with the concept of identity as individual, unique and essential. At the heart of CSI's depiction of identity crime is a neoliberal concern with the distinctive recognition of the singular person, as rooted in the self rather than the collective. The motif of disguise is now used to portray a wide range of characters that are attempting processes of self-transformation to render their bodies plastic and identities unstable, which, in turn, constructs them as perpetrators of a new type of identity crime.

\section{Self-Transformations:}

\section{A Freeing Process, or a New Identity Crime?}

Self-transformation narratives, usually depicted as some kind of premeditated alteration of both the body and the mind of an individual, are common throughout CSI. The Season 5 episode 'Who Shot Sherlock?' (5: 11) is illustrative of how the motif of disguise is reconfigured in the context of self-transformation narratives as it self-reflexively flirts with CSI's generic linkages to nineteenth-century detective fiction, while at the same time using disguised characters to discuss the role of self-transformation practices in contemporary society. The plot focuses on the murder of Dennis Kingsley (Ted Rooney). The divorced delivery guy is found dead in his basement, a meticulous recreation of the 'residence of the world's greatest detective'. The criminalists discover that Kingsley had immersed himself in the Holmesian universe along with three friends, but recently given up his hobby in an attempt to reconcile with his ex-wife. The investigation finally reveals that Kingsley was murdered by his friend Kay (Catherine Dent), as revenge for forcing her to give up her own 
alternate persona Irene Adler (a character from Doyle's short story 'A Scandal in Bohemia') when Kingsley tried to disband the club.

The perpetrator, the victim and the witnesses in this episode are all depicted as masquerading as 'someone else'. The unstable nature of the club members' identities is emphasised by juxtaposing their Holmesian personas with their everyday 'real-life' selves. When posing as Adler, Kay appears refined and as a highly intelligent upper-class woman. This assumption is overturned, however, when she is later depicted as a working-class woman using her sexuality to make an extra buck while waitressing. Kay's ability to pass as a member of a different social category partly evokes a generic link back to Doyle's portrayal of Irene Adler as a skilled swindler- 'The Woman' who actually manages to outwit Holmes by disguising herself as a young man. However, while Kay's disguise is depicted as an attempt at social mobility, it is not her aptitude to pass as upper class that is ultimately discussed as problematic in 'Who Shot Sherlock?'. Rather, it is her deep psychological wish to 'become someone else' that is constructed as the cause of her murderous rage and, by extension, a danger to society. Kay is not so much portrayed as a swindler as an individual who is perilously close to loosing her sense of self. The plotline ends with a confession, which draws heavily on the iconic scene from Psycho (1960) where Norman Bates (Anthony Perkins) regresses to his alternative persona: Mother. Wearing her everyday clothes, Kay suddenly starts ranting angrily in a British accent, a scene that suggests her attempt at selftransformation has resulted in a dangerous personality split. In this CSI episode, as in many others, the motif of disguise is newly used to worry at the potential malleability and instability of bodies and identities.

CSI creates a general sense of increased bodily indeterminacy by habitually featuring a wide variety of bodies and identities that have been altered in a range of different ways, including transsexuals in 'Ch-Ch-Changes' (5: 8) and 'Identity Crisis' (2: 13); civil war re-enactment buffs in 'Way to Go' (6:24); extreme body art practitioners in 'The Gone Dead Train' (9: 22); 'vampires' in 'Suckers' (4: 13); infantilists in 'King Baby' (5: 15); and animal role-players in 'Fur and Loathing' (4: 5) and 'Unleashed' (11: 19). Indicative of the selftransformation narratives featured in CSI is how they explicitly engage with the idea of 'the makeover' as constructed in women's magazines, daytime talk shows and - more recentlyreality TV. Makeover reality TV shows present a specific form of self-transformation narrative, where a regular person is aided by experts (medical, fashion, beautician) to successfully fulfil his/her wish to transform both mentally and corporeally. For example, 'The Hunger Artist' (2:23) and 'Crow's Feet' (5:4) both comment on the increased prominence of expert-led makeovers in the media, by dramatising the negative effects that fashion advice, dieting, beauty routines and plastic surgery can have on women's bodies and self-esteem.

CSI's concern with bodily plasticity grew more frequent in parallel with the arrival of the makeover reality TV genre, signalling both the prominent rise of 'makeover culture' but also how CSI actively engaged with the emergence of a new genre that shared the forensic crime drama's concern with bodily identity and new medical discoveries. Airing in the United States between September 2004 and May 2005, Season 5 featured a particularly high number of self-transformation narratives shortly after the explosion of makeover reality TV formats, including Extreme Makeover (2002-7), Plastic Surgery: Before and After (20026), Queer Eye for the Straight Guy (2003-7), The Swan (2004), Dr. 90210 (2004-), The Biggest Loser (2004-) and Brand New You (2005). Makeover shows of this period generally construct the act of self-transformation as a suitable way to alter one's sense of self in order to find happiness and success in life. In other words, this genre tends to construct selftransformation as a freeing process, potentially resulting in empowerment and emancipation. The increased prominence of the makeover narrative in popular culture, not least on 
television, has been discussed by Joanne Finkelstein (2007) as one of the most apparent expressions of what feminist philosopher Susan Bordo (1991, 106-30) called the inauguration of a 'paradigm of plasticity' in the late-twentieth century. Both the popularity of makeover reality TV and CSI's penchant for self-transformation narratives must be understood as part of a wider cultural engagement to imagine freedom from bodily determination (Bordo 1991), by depicting the possibility for everyone to transform themselves mentally and corporeally at will.

One characteristic of this discourse is that representatives of traditionally oppositional political agendas have articulated similarly celebratory perspectives on the idea of bodily plasticity. From a neoliberal viewpoint, the subject's ability to change his or her appearance at will is certainly understood as a positive expression of personal freedom. Conversely, the rejection of traditional essentialist understandings of identities (both exterior and interior) as inherent and static also harbours feminist potential to free the individual from naturalised power structures. From a feminist viewpoint, the understanding of bodies and identities as nomadic and fragmented becomes an empowering resistance against biological essentialism and age-old stereotypes. Many of CSI's self-transformation narratives include scenes where positive perspectives on plasticity are articulated. For example, the lead criminalist Gil Grissom (William Petersen) often delivers pedagogical monologues that reference both neoliberal and feminist frameworks for understanding bodily plasticity as a potentially empowering practice. For example, in 'Ch-Ch-Changes' (5: 8) Grissom expresses sympathy for transsexuals who have been refused sex change operations, by comparing humans to a type of oyster that can change gender at will. He suggests that maybe 'before man crawled out of the muck he had the same option. Maybe originally we where supposed to be able to switch genders. Maybe being born with just one sex is the mutation.'

However, while CSI acknowledges the wider cultural enthusiasm for plasticity, a far more negative perspective fundamentally saturates the programme's depiction of selftransformation narratives. Even though characters are portrayed as having transformed their bodies, identities and lives, these processes are ultimately depicted as resulting in unhappiness at best, and death at worse. Both 'The Hunger Artist' and 'Crow's Feet' feature deaths that are a direct result from extreme self-transformation practices. In 'The Hunger Artist', the criminalists investigate the death of an ex-model who suffered from body dysmorphic disorder and died from self-inflicted injuries sustained while attempting to correct aspects of her appearance she perceived as flawed. Similarly, 'Crow's Feet' offers detailed descriptions of extreme beauty routines that two middle-aged women have gone through, before dying from hydrogen peroxide injections meant to '[boost] the immune system and [reverse] the signs of aging'. Both episodes implicitly suggest that the victims' have - at least in some measure - caused their own deaths.

Other episodes go even further to criminalise self-transformation practices. ' $4 \mathrm{x} 4$ ' (5: 19), for example, problematises fitness culture, aligning bodybuilding and selfmedication practices with murder and a disfiguring deadly disease. On investigating the death of a body-builder (Jonny Miller) his fitness is revealed as a veneer when his right eye dissolves into black pus during the autopsy, exteriorising a grave state of interior decay caused by exposure to mould. The investigation traces this pathology back to blood and tissue covering a bullet lodged in the wall of the body-builder's apartment. He once shot a prostitute (Joy Hadnott) in a fit of rage, because the steroids he was taking made him both impotent and highly aggressive. Hence, this man's wish to transform his body by means of medication and extreme exercise is given as the cause of both his own, and the prostitute's, deaths. Selftransformation practices are continuously problematised as a new type of identity crime: untimely deaths resulting from attempts at bodily plasticity. 


\section{Unmasking Self-Transformed Bodies Through Inverted Makeovers}

CSI frequently constructs the self-transformation as an act of disguise. This by extension marks the plastic individual as, to some extent, deceitful. The series' depiction of forensic tools that identify and unmask altered bodies is often accomplished through a use of visual iconography closely associated with 'the makeover' and feature prominently as part of the reality TV format. In other words, CSI adopts some of most recognisable visual tropes from the makeover genre to literally and symbolically revoke the transformed body's ability to pass and ultimately reverse the process and return it to its 'original' shape or appearance. This is an example of how the engagement between two genres does not necessarily result in a simple import of meanings from one to the other, but rather enables a critical debate where an oppositional perspective is added to the wider cultural forum. CSI's take on makeover imagery produce a problematisation of bodily plasticity that casts it as deceitfully inauthentic, rather than a positive expression of personal freedom or empowerment.

Several of CSI's self-transformation narratives feature autopsy scenes that subtly diverge from the traditions established by earlier forensic crime dramas. Instead they evoke the graphic surgical imagery featured in makeover shows such as Extreme Makeover, Plastic Surgery: Before and After, Brand New You and Dr 90210. This development follows a gradual change that began with the pathology-centred UK dramas Silent Witness (1996-) and McCallum (1995-98), which, in turn, challenged the boundaries for depicting autopsies established by forensic crime dramas from the 1960s and 1970s like The Expert (BBC, 196876) and Quincy M.E (1976-83). CSI's spectacular autopsy footage follows in the footsteps of Silent Witness and McCallum when displaying the dead body on the slab pre- and postautopsy, as well as depicting the medical examiner covered in blood, holding organs for easy display. CSI has, however, gone further. The series has added the reverse-shot usually missing from earlier portrayals of the moment when the medical examiner actually cuts into the corpse. In addition to filming the medical examiner's face, CSI allows the viewers to see the scalpel penetrating the skin and internal organs in extreme close-up. In the context of selftransformation narratives (referring to the makeover genre in a number of ways), these graphic shots bring to mind the plastic surgery imagery familiar from makeover reality TV. This type of shot is quite rare in CSI, but features commonly in reality TV shows depicting surgery. Brenda R. Weber's analysis of plastic surgery imagery in makeover reality TV, suggests that these shows' spectacular portrayal of major medical operations can result in the genre's usual celebratory tone being lost in the 'cutting, blotting, sucking and restructuring' $(2009,23)$. CSI's autopsy imagery, in turn, evokes one of the most gruesome aspects of contemporary makeover culture. The surgical imagery comes with a set of negative connotations that are played up further when imported into CSI's wider problematisation of self-transformation practices.

In addition to this use of surgical footage, CSI frequently features 'before and after' imagery and the iconography of the 'reveal', two of those most characteristic tropes of the makeover TV narrative. 'Before and after' imagery typically comprises of two photos displayed side by side and constructed as depicting a temporal before and after. In turn, the 'reveal' is a generic scene at the end, where the newly transformed person is turned into a spectacle, displaying their transformation in front of friends and relatives (and, by extension, the television audience). Drawing on the respective analyses of such imagery by Anne M. Cronin $(2000,276)$ and Katariina Kyrölä $(2010,70-1)$, one can conclude that both tropes have a distinct future-oriented temporality within the context of makeover TV narratives, underlining the possibility of change. This generic function is essentially inverted in CSI as it incorporates these tropes into the forensic crime narrative. Both the 'after' imagery and the 
'reveal' are instead presented as displaying the pre-transformed body and so become oriented around the past, focusing on an original moment of stability and authenticity.

One representative example is the use of 'before and after' imagery in 'The Hunger Artist', which focuses on the self-inflicted death of ex-model Ashleigh (Tricia Helfer). The forensic investigation establishes that her immune system was weakened because of anorexia and bulimia, resulting in a fatal blood infection (contracted from excessively poking her skin with beauty tools and multiple botched botox injections). 'Before and after' imagery is one of the devices used to celebrate Ashleigh's 'original' body as beautiful and unique, implicitly suggesting that it would have remained so if she had not engaged in extreme attempts at self-transformation. The scene in question depicts the criminalists' process of identifying Ashleigh's body by placing two post-mortem photographs of her mutilated face side-by-side on a computer screen and then reconstructing what she used to look like. The image on the left, in the traditional place of the 'before' image, displays the deathly outcome of her attempts at self-transformation. However, the image on the right, replacing the traditional 'after' image, is digitally manipulated to create an image of Ashleigh's 'original' appearance. The dialogue between the criminalists also mimics the language of beauty experts in makeover TV shows, providing Ashleigh with 'a nice complexion' and a blonde, celebrity hairdo that looks 'like Courtney Love'. While the process formally echoes the iconography, temporality and function for the TV makeover narrative (making a previously 'abnormal' body 'beautiful'), the transformation is reversed. It restores Ashleigh's pre-transformed body to mark it as authentic, original and natural.

A similar effect is achieved in a scene in 'Fur and Loathing' (4: 5), where a suspect (Willie Garson) is brought in for questioning at the busy crime lab wearing a bright blue female cat suit. It is subsequently removed to reveal a bespectacled and balding man. The unmasking of this character is depicted as a spectacular moment where an 'authentic' identity is revealed. The camerawork mirrors the traditional 'reveal' of the makeover TV show by cutting away to audience faces at the very moment of unmasking, displaying their astonished reactions. The excitement about the 'new' body in makeover reality TV is thus transferred onto the 'original' body in the forensic crime drama. The 'reveal' becomes a process whereby the disguised or transformed body is stripped of its status as plastic and uncertain, revealing its 'true' identity.

Furthermore, Weber points out that makeover TV shows often construct the before-body as a 'spectacle of abnormality' $(2009,93)$ through a detailed visual mapping of the unsatisfactory parts of the body. This is perhaps most generically accomplished in scenes depicting pre-operative assessments, where a plastic surgeon draws on the patient's body with a marker pen. This trope has a counterpart in CSI's frequent depiction of the investigation processes as a mapping of the already transformed body's 'fake' parts. In 'Crow's Feet', the autopsy scenes of the dead women are juxtaposed with a sequence explicitly referencing the generic makeover trope described by Weber. Catherine Willows (Marge Helgenberger) visits a combined spa and medical practice (frequented by the victims). During the course of her interview with the doctor (Steven Brand) who runs the practice, he recommends various beauty procedures to her. We see him secretly photographing Catherine's face before mapping and retouching the features that would benefit from surgery. This process is echoed, but in reverse, during the autopsy scenes, where Dr Robbins' (Robert David Hall) postmortem identifies the part of the body that have been modified.

In more ways than one the forensic investigation becomes an inverted process of transformation that strips the plastic body of its various 'disguises' and restores a bodily identity constructed as authentic. From a genre studies perspective, it is interesting to note how any straightforward affinity with makeover reality TV is thus avoided. By inverting the 
generic functions of 'before and after' imagery, the 'reveal' and the mapping of undesirable pre-makeover body parts, CSI initiates a cultural conversation with makeover reality TV that articulates a distinctly different perspective on bodily plasticity. CSI's contribution to this cultural debate is uniquely informed by the programme's investment in essentialist genetics. To fully appreciate the ways in which CSI's perspective on bodily plasticity differ from that of most makeover TV shows it is important to understand exactly what is at stake when a forensic crime drama like CSI depicts self-transformation narratives.

\section{DNA, the Post-Genomic Moment and Newly Unidentifiable Bodies}

Unlike makeover reality TV, CSI's depiction of self-transformation narratives is structured by a strong investment in essentialist genetics, rooted in the crime genre's long-running portrayal of forensic science as able to identify individuals though inherent corporeal features, marks and traces. In earlier forensic crime dramas the fingerprint was the primary sign for an individual's inherent and unique corporeal identity. CSI continues this generic tradition, but with DNA evidence as the most important tool of modern forensics; the programme evokes essentialist ideas that cast DNA as a type of super-molecule harbouring detailed information about our 'true identities', our past and our future. This construction of DNA evidence is crucial for CSI's celebratory account of forensic science as an exceptional and trustworthy method of investigation. It is the unprecedented swiftness and absolute certainty of DNA analysis that makes the criminalists so successful.

CSI's problematisation of bodily plasticity is intrinsically tied to its investment in the determinist discourse that understands DNA as an intrinsic and unique blueprint of the human body. Following the strict logic of essentialist genetics, every attempt at bodily change becomes an attempt to oppose a genetic blueprint. This line of reasoning saturates most of the self-transformation narratives, but it is most clearly articulated in plotlines where attempts at curing diseased bodies are constructed as problematic examples of bodily plasticity. In other words, several episodes construct disease as a 'natural' biological process rooted in the genetic blueprint, and as such, medical intervention is presented as an unnatural act of human interference. In 'Justice is Served' (1:21) the female nutritionist, Dr. Hillridge's (played by Alicia Coppola) habit of murdering healthy athletic men and eating their most blood-filled organs is constructed as an extreme form of self-medication against porphyria (a genetic and potentially deadly disease affecting the skin and nervous system). Echoing extreme antimedication propaganda, CSI dramatises her genetic disease as the normal state of her body and by extension constructs her self-medication practices as an unnatural - even criminalintervention into a natural bodily process. This is achieved in part by depicting her selftransformation as a biological disguise that is shed in a final scene, with a close-up of her face deteriorating in fast-forward 'back' to its naturally diseased look, as if she was removing a mask of health. This perspective stands in stark contrast to the depiction of disease and health in most makeover TV shows. Characteristically, makeover reality TV celebrates the ability of modern medicine to render the body healthy, or more precisely, to make it look healthy. Physical traits commonly understood as external marks of disease or decay, such as ugly scars, bad teeth or fat, are first to be subjected to cosmetic change. The prospect of making the body look healthier is continuously presented as a positive and worthwhile motivation for the beautification process, in line with the current emphasis on self-help and 'body work' in contemporary culture.

In makeover reality $\mathrm{TV}$, the increased possibilities for medical intervention are always only celebrated and the medical experts are portrayed as trustworthy geniuses bettering and prolonging peoples lives. Conversely - and perhaps surprisingly - CSI often criticises groundbreaking medical procedures as unethical, unnatural and ultimately futile 
precisely because they oppose the notion of an essential genetic blueprint determining both who we are and what happens to our bodies within the natural order of things. The episode 'Organ Grinder' (2: 11), for example, problematises organ transplants based on this premise. The criminalists can only prove that a crime has been committed by testing the only body-part remaining from a victim who has potentially been poisoned, namely: a kidney donated before his death. The organ recipient (John F. O'Donohue) is initially unwilling, as the procedure could reduce his own chance of survival. The criminalists are about to give up, but the man changes his mind when his body starts to reject the kidney. Crucially, the phenomenon of rejection is not depicted as a result of the kidney being poisonous, but as natural, caused by the man's own antibodies. Echoing the wider tendency for 'cultural rejection' of organ transplants as outlined by Donald Joralemon (1995, 337-9), this episode implicitly constructs the procedure as an unnatural modification where the naturally bounded body fights an invading organ. The fact that the recipient's watch stopped during the transplant operation is discussed as indicating that his 'time was up' and he should be allowed to die 'naturally'.

CSI's self-transformation narratives are governed by a fear that bodily change will result in a loss of the body's 'natural' and enclosed singularity. Furthermore, the fact that even cases of medical intervention are problematised articulates an accelerated sense of urgency with regards to bodily plasticity. I propose that this desperation is caused by the fact that CSI attempts to hail DNA's status as a reliable marker of identity at the very moment that molecular science - the scientific field that seemingly proved bodily identity as inherent not so long ago - has started to question genetic essentialism in a number of fundamental ways. Suggested by various scholars mapping scientific discourses in contemporary culture (Keller 2005, 3-6; Rose 2007, 17-21, 40-7; Franklin 2000, 190), the early 2000s has been characterised by an emergent shift, whereby the reductionism of genetic essentialism and determinism has been increasingly exchanged for a post-genomic systems biology which emphasises complex interactions on the level of genes and molecules

The emergence of this post-genomic discourse is largely engendered by the aftermath of a number of attempts to decipher the hidden information in DNA, at the pinnacle of the genomic era in the 1980s and 1990s. The Human Genome Project was initiated as an endeavour aiming to fulfil the essentialist genetic promise of transparency and readability. If the message hidden inside the gene could be decoded, science would finally be able to understand and explain life itself. In hindsight it became clear that rather than producing straightforward answers, molecular science raised even more questions and the exact function of most genes remains largely unexplained. With this insight, there has been a gradual change in perspective, with the reductionism of essentialist genetics increasingly understood as somewhat old-fashioned (Rose 2001, 14; Rabinow and Caduff 2006, 329-30). Furthermore, the aim to decipher the genetic code has been replaced by a post-genomic focus on genetic engineering and 'computational biology' (Franklin 2007, 33). As Nikolas Rose (2007, 40) contends, the body is now not only understood as malleable through medico-surgical interventions on a molar level of limbs and organs, but on the level of molecules and genes, which results in a more fundamental questioning of the idea of an essential core identity hidden within our chemistry. The possibilities of gene therapy and genetic engineering provide more extreme forms of bodily plasticity than ever before, seemingly allowing us to change the very blueprint of who we are.

This shift is not only enacted within the scientific community, but popular culture also takes an active role in articulating and investigating the wider implications of this post-genomic sensibility. For example, CSI features several episodes that deal with the cultural implications of different types of gene therapies. One of the most illustrative episodes is 'Harvest' (5: 3). It presents a case of genetic engineering as instigating events that result in 
the murder of a young girl called Alicia (Briann Benali), a so-called 'designer baby' conceived in vitro as the perfect genetic match to her older brother (Ramon De Ocampo), who is dying of leukaemia. In line with CSI's overall investment in essentialist genetics, the episode dramatises gene therapy as leading to problems of misrecognition and multiple types of identity loss. The investigation into Alicia's life reveals how she was forced to give up her own interests, activities and social life and exist solely as a donor for her sick brother. Her loss of social identity is biologically echoed in her genetic identity, which has been lost to her brother through a bone marrow transplant: Alicia's blood is literally flowing through his veins. Circumstantial evidence indicates that the brother killed his sister out of mercy, to end her suffering from the medical procedures she has undergone. There is, however, no actual physical proof, as the DNA evidence left behind only traces back to Alicia. The gene therapy has supplied him with the ultimate biological alibi: the lack of a unique DNA profile.

This episode is a clear example of how CSI's treatment of medically enabled bodily change articulates a central issue of the post-genomic moment; the idea that recent discoveries in molecular science will not only result in a loss of 'natural' singularity, but also in un-identifiability. Jackie Stacey (2010) names this issue the perceived 'problem of misrecognition' (148) as she discusses discourses on genetics and bodily plasticity in films dealing with cloning. According to Stacey, the clone is a cultural figure that most clearly embodies cultural fears about 'an uncanny synthesis of sameness and difference, defying the conventional demarcations around the singularity of the human body' $(2010,95)$. Her analysis suggests that the body is redefined in fundamental ways by new medical interferences in genetic processes, resulting in an acute loss of 'bio-aura' (2010, 179-94). In using the term of bio-aura, she suggests, with reference to Walter Benjamin (2008), that the process of cloning is best understood as producing a similar reaction as when art becomes mechanically reproduced through photography. Medico-scientific interventions are similarly understood as stripping the body of its materially rooted in authenticity and singular nature.

Although CSI never depicts cloning practices - which generally function as a more literal symbol for the idea of an exact biological copy produced through genetic technologies - the programme can still be understood as dramatising a similar loss of bio-aura when depicting characters that lack a unique set of DNA. Alicia and her brother are used to express worries that something essential might be lost in the process of genetic intervention, be it the 'body's singularity, nonrepeatability, uniqueness, integrity' (Stacey 2010, 182) ormore specific to CSI - its identifiability. Furthermore, the invisible nature of the genetic manipulation depicted in 'Harvest' is a crucial aspect of CSI's dramatisation of gene therapy as a new and highly problematic type of identity crime. Genetic manipulation is constructed as the most extreme form of criminal disguise, leaving no visible trace of the change, allowing the individual to pass effortlessly and inherently as someone else.

\section{Concluding Remarks}

CSI participates in the same cultural debate on bodily plasticity as makeover reality TV, but its particular contribution to this conversation is governed by an investment in essentialist genetics that articulates a different perspective from the makeover genre. On the one hand, CSI suggests that the act of self-transformation renders one unnatural, inauthentic and potentially unidentifiable, because it stands in opposition to the 'true self' as inscribed in one's genetic blueprint. Makeover reality TV, on the other hand, depicts change as conversely allowing for the exterior appearance of the previously hidden true self. Hence, both types of self-transformation narratives actually articulate ideas about the authentic self, albeit different in kind. Whereas CSI's notion of identity is tied to the genetic imaginary and thus firmly corporeal, makeover reality TV rather subscribes to a psychologically inspired self-help 
paradigm where identity is ultimately rooted in the mind. As indicated in several scholarly studies, the makeover is usually presented as a process whereby the inner mental self can finally be externalised (Crawley 2006, 59; Heyes 2007, 21; Kyrölä 2010, 69-73). The afterbody is authenticated through an assurance that the transformed body is a more true reflection of the individuals' inner self. Both makeover reality television and CSI can be said to articulate ideas about identity as somehow inherent and stable. However, the fundamental difference is that the makeover TV shows construct the concept of the true self as immaterial (referring to concepts such as the soul or the mind), while CSI is heavily invested in DNA as the locus of the true self, understanding identity as essentially biological.

However, it is also worth pointing out that CSI's frequent depiction of selftransformation narratives also results in a heightened sense of the potential unpredictability and uncertainty of contemporary corporeality. Even though CSI continuously problematises bodily plasticity and celebrates corporeal identifiability, it inadvertently suggests that there are far greater possibilities for change than ever before. In comparison with makeover reality TV, CSI actually presents a far wider range of possibilities for self-transformation, in spite of its much more critical perspective on bodily plasticity. All the transsexuals, extreme body art practitioners, role-players, self-medicaters and designer babies featured in CSI transgress the usual modes of self-transformation presented in makeover reality TV, a genre which is known for adhering strictly to traditional norms of gender, sex and sexuality, class and age. Albeit formally problematised and ultimately constructed as a new identity crime, the biomedically plastic body in CSI could be understood as a potentially transgressive post-genomic figure that at least in part revises both the forensic crime drama and the makeover TV narrative. This shows that genre revision, crossbreeding and engagement are crucial practices for popular television, which connect long-running generic elements to new cultural anxieties and engender a more multifaceted cultural conversation.

\section{References}

Benjamin, Walter. 2008. The Work of Art in the Age of Mechanical Reproduction. London: Penguin Books Limited.

Biggest Loser, The. 2004-. NBC, 3Ball Productions, Eyeworks, Shine America, Twenty Five Seven Productions.

Bordo, Susan. 1991. "Material Girl': The Effacements of Postmodern Culture'. In The Female Body: Figures, Styles, Speculations, edited by Laurence Goldstein, 106-130. Ann Arbor: University of Michigan Press.

Brand New You. 2005. Channel 5, RDF Media.

Brooks, Peter. 2007. 'The Identity Paradigm'. In Stories and Portraits of the Self, edited by Helena Carvalhão Buescu and João Ferreira Duarte, 149-150. Amsterdam and New York: Radopi.

Craig Kennedy. Criminologist. 1952. Weiss Productions.

Crawley, Melissa. 2006. 'Making Over the New Adam'. In The Great American Makeover: Television, History, Nation, edited by Dana Heller, 51-64. New York: Palgrave Macmillan.

Cronin, Anne M. 2000. 'Consumerism and Compulsory Individuality: Women, will and potential'. In Transformations: Thinking Through Feminism, edited by Sarah Ahmed, Jane Kilby, Celia Lury, Maureen McNeil and Beverly Skeggs. London and New York: Routledge.

CSI: Crime Scene Investigation. 2000-. CBS, Alliance Atlantis Communications, CBS Paramount Network Television, Jerry Bruckheimer Television.

Dr. 90210. 2004-. E! Entertainment Television. 
Expert, The. 1968-76. BBC.

Extreme Makeover. 2002-07. ABC, Lighthearted Entertainment.

Finkelstein, Joanne. 2007. The Art of Self Invention: Image and Identity in Popular Visual Culture. London: I.B. Tauris.

Franklin, Sarah. 2000. 'Global Nature and the Genetic Imaginary'. In Global Nature, Global Culture, edited by Sarah Franklin, Celia Lury and Jackie Stacey, 188-227. London: SAGE Publications.

Franklin, Sarah. 2007. Dolly Mixtures: The Remaking of Genealogy. Durham and London: Duke University Press.

Friedman, Lawrence M. 1991. 'Crimes of Mobility', Stanford Law Review 43: 637-658.

Harrington, Ellen Burton. 2007. 'Nation, Identity and the Fascination of Forensic Science in Sherlock Holmes and CSI', International Journal of Cultural Studies 10 (3): 365-382.

Heyes, Cressida J. 2007. 'Cosmetic Surgery and the Televisual Makeover: A Foucauldian Feminist Reading', Feminist Media Studies 7 (1): 17-32.

Joralemon, Donald. 1995. 'Organ Wars: The Battle for Body Parts', Medical Anthopology Quarterly 9 (3): 335-356.

Keller, Evelyn Fox. 2005. 'The Century Beyond the Gene', Journal of Bioscience 30 (1): 310.

Kyrölä, Katariina. 2010. The Weight of Images: Affective Engagements with Fat Corporeality in the Media, PhD diss, University of Turku.

Lindberg, Gary H. 1981. The Confidence Man in American Literature. Oxford: Oxford University Press.

McCallum. 1995-98. ITV, Scottish Television Enterprises.

Murnaghan, Sheila. 1987. Disguise and Recognition in the Odyssey, Princeton, NJ: Princeton University Press.

Newcomb, Horace M., and Paul M. Hirsch. 1983. 'Television as a Cultural Forum: Implications for Research', Quarterly Review of Film Studies 8 (3): 45-55.

Psycho. 1960. Directed by Alfred Hitchcock. USA: Shamley Productions.

Plastic Surgery: Before and After. 2002-06. Discovery Health, Original Productions/Outdoor Life Network and Discovery Channel.

Queer Eye for the Straight Guy. 2003-07. Bravo, Bravo Original Production/Scout Productions.

Quincy M.E. 1976-83. NBC, Flen A. Larson Productions/Universal TV.

Rabinow, Paul, and Carlo Caduff, 2006. 'Life - After Canguilhem', Theory, Culture \& Society 23: 329-331.

Rose, Nikolas. 2001.'The Politics of Life Itself', Theory, Culture \& Society 18(6): 1-30.

Rose, Nikolas. 2007. The Politics of Life Itself: Biomedicine, Power, and Subjectivity in the Twenty-First Century. Princeton: Princeton University Press.

Silent Witness. 1996-. BBC, A\&E Television Networks, Cipango Productions Audiovisuelles.

Stacey, Jackie. 2010. Cinematic Life of the Gene. Durham: Duke University Press.

Swan, The. 2004. Fox, A. Smith \& Co. Productions, George Paige Associates, Galan Entertainment.

Thomas, Ronald R. 1999. Detective Fiction and The Rise of Forensic Science. Cambridge: Cambridge University Press.

Weber, Brenda R. 2009. Makeover TV: Selfhood, Citizenship, and Celebrity. Durham: Duke University Press. 